\title{
The Fishes collected by the "Huxley" from the North Side of the Bay of Biscay in August, 1906.
}

By

\author{
L. W. Byrne.
}

With one Figure in the Text.

ONLY one species met with on this cruise appears to have been previously undescribed.

Although all the other species were already known from similar localities in the North-east Atlantic, attention may be called to an interesting series of the young of Synaphobranchus pinnatus and to the capture of numerous young examples of Onus biscayensis.

When compared with the results of the hauls taken by H.M.S. Research, a little farther south and over very much deeper soundings, the list of species taken by the Huxley is chiefly remarkable for the entire absence of Stomias boa, Gonostoma microdon, and G. bathyphilum, the range of none of which seems to extend into waters as shallow as those fished by the Huxley.

\section{Stomiatidae.}

Maurolicus borealis, Nilsson.

The small fish trawl took two damaged larvæ (about $7.5 \mathrm{~mm}$. long) at Station VIII.* and very many young, one of $27 \mathrm{~mm}$. and 98 others of all sizes between 20 and $12 \mathrm{~mm}$., at Station X.

Conger vulgaris, Cuv.

\section{Anguillidae.}

A leptocephalus of this species (kindly identified for me by Dr. Schmidt) $141 \mathrm{~mm}$. long was taken in the small fish trawl at Station VIII.

\section{SyNaphobranchidaE.}

Synaphobranchus pinnatus, Gthr.

Fourteen specimens, 105 to $270 \mathrm{~mm}$. in length, were taken at Station XII., on fine sand at a depth of 246 fathoms.

This series serves to connect the small specimen taken by the Helga (Fisheries, Ireland, Sci. Invest., 1905, ii. [1906]) with examples having

* For the positions of the Stations see Table on p. 5. 
the form and characters of the adult, and dispels any doubt as to the correct identification of the former specimen.

The relative distance of the origins of the dorsal and anal fins from the snout is subject to considerable individual variation; and the length of the head is contained $2 \frac{1}{2}$ to $3 \frac{1}{4}$ times in the distance from the snout to the origin of the dorsal fin, 2 to $2 \frac{1}{4}$ times in the distance from the snout to the origin of the anal fin, and half to slightly more than once in the interval between the origins of the two fins, which is relatively shortest in the two smallest examples.

The belly of the smallest specimen, $105 \mathrm{~mm}$. long, was distended by the vertebra of another fish about $4 \mathrm{~mm}$. long and $3 \mathrm{~mm}$. in diameter, to which fragments of flesh still adhered.

\section{SCOPELIDAE.}

Scopelus (Myctophum) glacialis, Reinhdt.

Nine specimens, 38 to $12 \mathrm{~mm}$. in length (without caudal fins) were taken at or near the surface at Station VIII.

S. (M.) punctatus, Raf.

Ten specimens, 37 to $20 \mathrm{~mm}$. in length (without caudal fins), were taken in the same haul as the last species. In these specimens the superanal photophores numbered $7-9+8-10$, and the posterolateral varied somewhat in position, being either above the break in the superanal series or above the last photophore anterior to the break.

S. (Lampanyctus) crocodilus, Risso.

A single damaged specimen $21 \mathrm{~mm}$. long (without caudal fin) was taken in an Agassiz trawl at Station XII. There is nothing to show the precise depth at which it entered the net.

The small fish trawl at Station X. contained the remains of Scopelus larvæ, too broken for specific determination.

Paralepis sp.

“Long-anal" larva. Holt \& Byrne, Trans. Linn. Soc., x. p. 199.

A damaged specimen about $29 \mathrm{~mm}$. long from Station X.

\section{Syngnathidae.}

Nerophis aequoreus, var. exilis, H. and By., was taken by the small fish trawl, worked as near the surface as possible, at Stations VIII. (nineteen; $177-43 \mathrm{~mm}$.) and $\mathrm{X}$. (two; 220 and $105 \mathrm{~mm}$.). The smallest ovigerous male captured was $150 \mathrm{~mm}$. long.

\section{Gadidae.}

Phycis blennioides, Brunner.

Nine specimens (145 to $85 \mathrm{~mm}$. long) were taken at Station IX. on 
fine sand in about 240 fathoms of water, and a single specimen $(108 \mathrm{~mm}$. long) at Station XII. on similar ground at about the same depth.

Onus sp.

Six specimens of a tricirrate Onus from 60 to $109 \mathrm{~mm}$. long from Station VII. cannot at present be satisfactorily referred to any described species and, in view of the difficulties attending the satisfactory determination of isolated specimens belonging to this genus, it seems best to await further material before applying any name to them.

Drs. Schmidt and Jensen have kindly compared the specimens with O. Reinhardti of a comparable size, and inform me that they certainly do not belong to that species, while they also appear to be distinguishable from 0 . Carpenteri, Gthr., and 0 . macrophthalmus, Gthr.

The specimens were taken with the Agassiz trawl, which came up filled with large masses of coral.

Onus biscayensis, Collett.

Small examples occurred as follows, in each case on sandy ground:

Station II.-One, $61 \mathrm{~mm}$.

Station IX.-Two, 62 and $54 \mathrm{~mm}$.

Station XIII.-Seven, 64 to $48 \mathrm{~mm}$.

The broken remains of two small fishes from Station XIII.are probably referable to either this or the preceding species.

Specimens of the size captured appear to have the back ordinarily greyish-brown in colour with obscure marblings of a darker shade which become less conspicuous with growth.

\section{Pleuronectidae.}

Arnoglossus laterna (Walb.).

Two specimens, 89 and $40 \mathrm{~mm}$. long, at Station II. (75-80 fathoms), and two, 140 and $37 \mathrm{~mm}$. long, at Station XI. (146 fathoms).

The larger example taken at the latter station showed the character of " A. lophotes."

Zeugopterus megastoma (Donov.).

A single specimen of $175 \mathrm{~mm}$. at Station II. and three smaller ones (73-53 mm.) at Station XI.

Damaged larvæ (about an inch long in each case) were taken by the small fish trawl at Stations VIII. (one) and X. (one).

Solea variegata (Donov.).

A single specimen, $110 \mathrm{~mm}$. long, at Station VIII.

Gobius Jeffreysii, Gthr.

GobIIDAe.

A single specimen of $21 \mathrm{~mm}$. at Station $\mathrm{X}$. and fourteen others of 32 to $20 \mathrm{~mm}$. at Station XI. 
Pteridium Alleni, Byrne.*

\section{LYCODIDAE.}

The specimen on which this species was founded was taken at Station VII. in about 444 fathoms. The specimen was taken with the Agassiz trawl, which came up filled with large masses of coral.

The original description and sketch of this species are (by the kind permission of the editor of the Annals and Magazine of Natural History) repeated below :-

Form stout; body compressed in caudal region, its greatest height about 4 times in its length (without caudal fin). Head depressed, $3 \frac{1}{2}$ times in length (without caudal), nearly twice as long as broad, its breadth about equal to its height at isthmus. Snout rounded, with numerous mucous glands, about $4 \frac{1}{4}$ times in head. Eye of moderate size, longer than the flat interorbital space is wide, 6 times in head and less than $1 \frac{1}{2}$ times in snout. Gape $2 \frac{3}{5}$ times in head, barely reaching

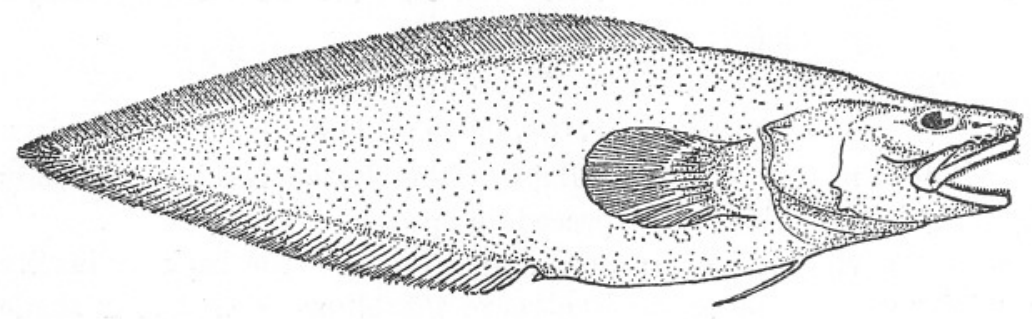

Pteridium Alleni, $\times 1$.

beyond the level of the hind margin of orbit; maxilla weak, and but little expanded distally. Villiform teeth in both jaws and in a V-shaped band on vomer.

Marginal fins continuous, their bases covered with skin and scales; fin-rays difficult to count, probably D. $c a .90$, A. $c a .55$. Ventrals each with two closely apposed rays.

Body covered with a copious mucous secretion; scales very small, approximately 105 in a longitudinal and 35 in a transverse series. Lateral line very indistinct and broken.

Colour, after preservation, umber-brown, darker on top of head and front part of dorsum, paler on belly. Rays of marginal fins dark.

Length of type, $101 \mathrm{~mm}$. (96 mm. without caudal).

$H a b$. Mouth of English Channel, near La Chapelle Bank, $c a$. 450 fath.

* P. Alleni, Byrne, Ann. Mag. Nat. Hist., Ser. 7, vol. xviii. p. 448 (Dec., 1906). 


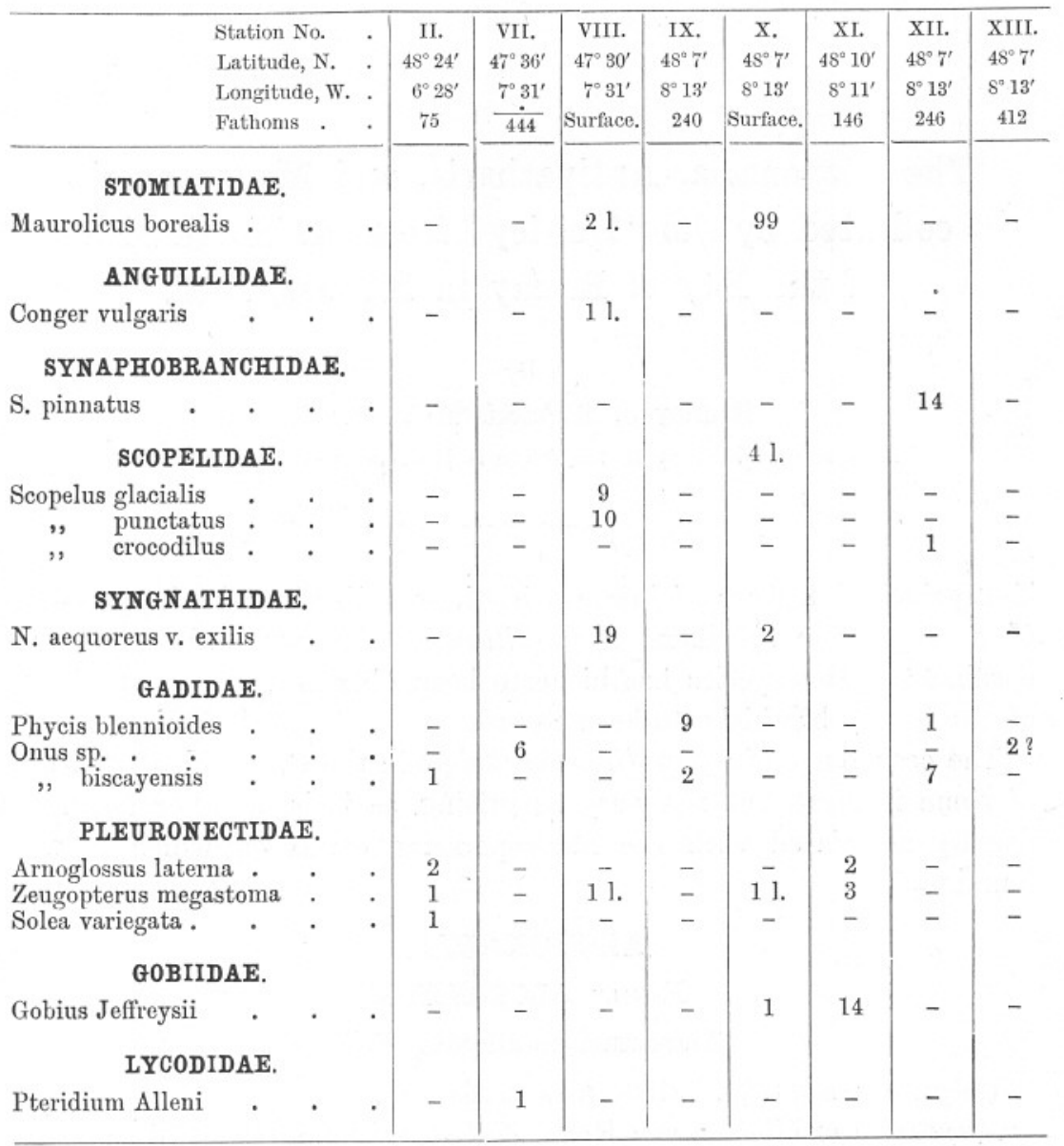

